\title{
Glycine receptors (version 2020.4) in the IUPHAR/BPS Guide to Pharmacology Database
}

\author{
Joseph. W. Lynch ${ }^{1}$, Lucia G. Sivilotti ${ }^{2}$ and Trevor G. Smart ${ }^{2}$ \\ 1. University of Queensland, Australia \\ 2. University College London, UK
}

\begin{abstract}
The inhibitory glycine receptor (nomenclature as agreed by the NC-IUPHAR Subcommittee on Glycine Receptors) is a member of the Cys-loop superfamily of transmitter-gated ion channels that includes the zinc activated channels, $\mathrm{GABA}_{\mathrm{A}}$, nicotinic acetylcholine and $5-\mathrm{HT}_{3}$ receptors and $\mathrm{Zn}^{2+}$ - activated channels. The receptor is expressed either as a homo-pentamer of $\alpha$ subunits, or a complex now thought to harbour $2 \alpha$ and $3 \beta$ subunits $[32,7]$, that contain an intrinsic anion channel. Four differentially expressed isoforms of the $\alpha$-subunit ( $\alpha 1-\alpha 4)$ and one variant of the $\beta$-subunit $(\beta 1, G L R B, P 48167)$ have been identified by genomic and cDNA cloning. Further diversity originates from alternative splicing of the primary gene transcripts for $\alpha 1$ ( $\alpha 1^{\text {INS }}$ and $\left.\alpha 1^{\text {del }}\right), \alpha 2$ ( $\alpha 2 A$ and $\left.\alpha 2 B\right), \alpha 3$ ( $\alpha 3 S$ and $\alpha 3 L$ ) and $\beta(\beta \Delta 7)$ subunits and by mRNA editing of the $\alpha 2$ and $\alpha 3$ subunit $[82,92,20]$. Both $\alpha 2$ splicing and $\alpha 3$ mRNA editing can produce subunits (i.e., $\alpha 2 B$ and $\alpha 3 \mathrm{P} 185 \mathrm{~L})$ with enhanced agonist sensitivity. Predominantly, the adult form of the receptor contains $\alpha 1$ (or $\alpha 3$ ) and $\beta$ subunits whereas the immature form is mostly composed of only $\alpha 2$ subunits. The \&a;pha; 4 subunit is a pseudogene in humans. High resolution molecular structures are available for the $\alpha 1$ and $\alpha 3$ homomeric receptors [49, 19]. As in other Cys-loop receptors, the orthosteric binding site for agonists and the competitive antagonist strychnine is formed at the interfaces between the subunits' extracellular domains. Inclusion of the $\beta$-subunit in the pentameric glycine receptor contributes to agonist binding, reduces single channel conductance and alters pharmacology. The $\beta$-subunit also anchors the receptor, via an amphipathic sequence within the large intracellular loop region, to gephyrin. This a cytoskeletal attachment protein that binds to a number of subsynaptic proteins involved in cytoskeletal structure and thus clusters and anchors hetero-oligomeric receptors to the synapse $[55,53,87]$. G protein $\beta y$ subunits enhance the open state probability of native and recombinant glycine receptors by association with domains within the large intracellular loop [123, 122]. Intracellular chloride concentration modulates the kinetics of native and recombinant glycine receptors [95]. Intracellular $\mathrm{Ca}^{2+}$ appears to increase native and recombinant glycine receptor affinity, prolonging channel open events, by a mechanism that does not involve phosphorylation [26]. Extracellular $\mathrm{Zn}^{2+}$ potentiates GlyR function at nanomolar concentrations [85]. and causes inhibition at higher micromolar concentrations (17).
\end{abstract}

\section{Contents}

This is a citation summary for Glycine receptors in the Guide to Pharmacology database (GtoPdb). It exists purely as an adjunct to the database to facilitate the recognition of citations to and from the database by citation analyzers. Readers will almost certainly want to visit the relevant sections of the database which are given here under database links.

GtoPdb is an expert-driven guide to pharmacological targets and the substances that act on them. GtoPdb is a reference work which is most usefully represented as an on-line database. As in any publication this work should be appropriately cited, and the papers it cites should also be recognized. This document provides a citation for the relevant parts of the database, and also provides a reference list for the research cited by those parts.

Please note that the database version for the citations given in GtoPdb are to the most recent preceding version in which the family or its subfamilies and targets were substantially changed. The links below are to the current version. If you need to consult the cited version, rather than the most recent version, please contact the GtoPdb curators.

\section{Database links}

Glycine receptors 
http://www.guidetopharmacology.org/GRAC/FamilyDisplayForward?familyld=73

Introduction to Glycine receptors

http://www.guidetopharmacology.org/GRAC/FamilyIntroductionForward?familyld=73

Channels and Subunits

Complexes

Glycine Receptor (All subtypes)

http://www.guidetopharmacology.org/GRAC/ObjectDisplayForward?objectld=428

Subunits

glycine receptor $\alpha 1$ subunit

http://www.guidetopharmacology.org/GRAC/ObjectDisplayForward?objectld=423

glycine receptor $\alpha 2$ subunit

http://www.guidetopharmacology.org/GRAC/ObjectDisplayForward?objectld=424

glycine receptor $\alpha 3$ subunit

http://www.guidetopharmacology.org/GRAC/ObjectDisplayForward?objectld=425

glycine receptor a4 subunit (pseudogene in humans)

http://www.guidetopharmacology.org/GRAC/ObjectDisplayForward?objectld=426

glycine receptor $\beta$ subunit

http://www.guidetopharmacology.org/GRAC/ObjectDisplayForward?objectld=427

\section{References}

1. Ahrens J, Demir R, Leuwer M, de la Roche J, Krampfl K, Foadi N, Karst M and Haeseler G. (2009) The nonpsychotropic cannabinoid cannabidiol modulates and directly activates alpha-1 and alpha-1-Beta glycine receptor function. Pharmacology 83: 217-22 [PMID:19204413]

2. Aprison $\mathrm{MH}$ and Werman R. (1965) The distribution of glycine in cat spinal cord and roots Life Sci. 4: 2075-83 [PMID:5866625]

3. Araki T, Yamano M, Murakami T, Wanaka A, Betz H and Tohyama M. (1988) Localization of glycine receptors in the rat central nervous system: an immunocytochemical analysis using monoclonal antibody. Neuroscience 25: 613-24 [PMID:2840602]

4. Bakker MJ, van Dijk JG, van den Maagdenberg AM and Tijssen MA. (2006) Startle syndromes.Lancet Neurol 5: 513-24 [PMID:16713923]

5. Balse E, Tessier LH, Forster V, Roux MJ, Sahel JA and Picaud S. (2006) Glycine receptors in a population of adult mammalian cones. J. Physiol. (Lond.) 571: 391-401 [PMID:16396929]

6. Beato M, Groot-Kormelink PJ, Colquhoun D and Sivilotti LG. (2002) Openings of the rat recombinant alpha 1 homomeric glycine receptor as a function of the number of agonist molecules bound. J. Gen. Physiol. 119: 443-66 [PMID:11981023]

7. Betz $\mathrm{H}$ and Laube B. (2006) Glycine receptors: recent insights into their structural organization and functional diversity. J. Neurochem. 97: 1600-10 [PMID:16805771]

8. Bloomenthal AB, Goldwater E, Pritchett DB and Harrison NL. (1994) Biphasic modulation of the strychnine-sensitive glycine receptor by Zn2+. Mol. Pharmacol. 46: 1156-9 [PMID:7808436]

9. Bormann J, Rundström N, Betz H and Langosch D. (1993) Residues within transmembrane segment M2 determine chloride conductance of glycine receptor homo- and hetero-oligomers. EMBO J. 12: 3729-37 [PMID:8404844]

10. Breitinger U and Breitinger HG. (2020) Modulators of the Inhibitory Glycine Receptor ACS Chem Neurosci 11: 1706-1725 [PMID:32391682]

11. Buckwalter MS, Cook SA, Davisson MT, White WF and Camper SA. (1994) A frameshift mutation in the mouse alpha 1 glycine receptor gene (Glra1) results in progressive neurological symptoms and juvenile death. Hum. Mol. Genet. 3: 2025-30 [PMID:7874121]

12. Burzomato V, Beato M, Groot-Kormelink PJ, Colquhoun D and Sivilotti LG. (2004) Single-channel behavior of heteromeric alpha1beta glycine receptors: an attempt to detect a conformational change before the channel opens. J. Neurosci. 24: 10924-40 [PMID:15574743]

13. Callister RJ and Graham BA. (2010) Early history of glycine receptor biology in Mammalian spinal cord circuits. Front Mol Neurosci 3: 13 [PMID:20577630]

14. Curtis DR, Hösli $L$ and Johnston GA. (1967) Inhibition of spinal neurons by glycine.Nature 215: 1502-3 [PMID:4293850]

15. Curtis DR and Malik R. (1985) Glycine antagonism by RU 5135.Eur. J. Pharmacol. 110: 383-4 [PMID:4007055]

16. De Saint Jan D, David-Watine B, Korn H and Bregestovski P. (2001) Activation of human alpha1 and alpha2 homomeric glycine receptors by taurine and GABA. J. Physiol. (Lond.) 535: 741-55 [PMID:11559772]

17. Demir R, Leuwer M, de la Roche J, Krampfl K, Foadi N, Karst M, Dengler R, Haeseler G and Ahrens J. (2009) Modulation of glycine receptor function by the synthetic cannabinoid HU210. Pharmacology 83: 270-4 [PMID:19307742]

18. Dlugaiczyk J, Singer W, Schick B, Iro H, Becker K, Becker CM, Zimmermann U, Rohbock K and Knipper M. (2008) Expression of glycine receptors and gephyrin in the rat cochlea. Histochem. Cell Biol. 129: 51323 [PMID:18231803]

19. Du J, Lü W, Wu S, Cheng Y and Gouaux E. (2015) Glycine receptor mechanism elucidated by electron 
cryo-microscopy. Nature 526: 224-9 [PMID:26344198]

20. Eichler SA, Kirischuk S, Jüttner R, Schafermeier PK, Legendre P, Lehmann TN, Gloveli T, Grantyn R and Meier JC. (2008) Glycinergic tonic inhibition of hippocampal neurons with depolarizing GABAergic transmission elicits histopathological signs of temporal lobe epilepsy. J. Cell. Mol. Med. 12: 2848-66 [PMID:19210758]

21. Findlay GS, Harris RA and Blednov YA. (2005) Male transgenic glycine receptor alpha1 (S267Q) mutant mice display a hyperekplexia-like increase in acoustic startle responses. Pharmacol. Biochem. Behav. 82: 215-22 [PMID:16168470]

22. Findlay GS, Phelan R, Roberts MT, Homanics GE, Bergeson SE, Lopreato GF, Mihic SJ, Blednov YA and Harris RA. (2003) Glycine receptor knock-in mice and hyperekplexia-like phenotypes: comparisons with the null mutant. J. Neurosci. 23: 8051-9 [PMID:12954867]

23. Findlay GS, Wick MJ, Mascia MP, Wallace D, Miller GW, Harris RA and Blednov YA. (2002) Transgenic expression of a mutant glycine receptor decreases alcohol sensitivity of mice. J. Pharmacol. Exp. Ther. 300: 526-34 [PMID:11805213]

24. Fritschy JM, Harvey RJ and Schwarz G. (2008) Gephyrin: where do we stand, where do we go?Trends Neurosci. 31: 257-64 [PMID:18403029]

25. Froh M, Thurman RG and Wheeler MD. (2002) Molecular evidence for a glycine-gated chloride channel in macrophages and leukocytes. Am. J. Physiol. Gastrointest. Liver Physiol. 283: G856-63 [PMID:12223345]

26. Fucile S, De Saint Jan D, de Carvalho LP and Bregestovski P. (2000) Fast potentiation of glycine receptor channels of intracellular calcium in neurons and transfected cells. Neuron 28: 571-83 [PMID:11144365]

27. Ge LH, Lee SC, Liu J and Yang XL. (2007) Glycine receptors are functionally expressed on bullfrog retinal cone photoreceptors. Neuroscience 146: 427-34 [PMID:17346892]

28. Greferath U, Brandstätter JH, Wässle H, Kirsch J, Kuhse J and Grünert U. (1994) Differential expression of glycine receptor subunits in the retina of the rat: a study using immunohistochemistry and in situ hybridization. Vis. Neurosci. 11: 721-9 [PMID:7918222]

29. Grenningloh G, Pribilla I, Prior P, Multhaup G, Beyreuther K, Taleb O and Betz H. (1990) Cloning and expression of the $58 \mathrm{kd}$ beta subunit of the inhibitory glycine receptor. Neuron 4: 963-70 [PMID:2163264]

30. Grenningloh G, Rienitz A, Schmitt B, Methfessel C, Zensen M, Beyreuther K, Gundelfinger ED and Betz H. (1987) The strychnine-binding subunit of the glycine receptor shows homology with nicotinic acetylcholine receptors. Nature 328: 215-20 [PMID:3037383]

31. Grenningloh G, Schmieden V, Schofield PR, Seeburg PH, Siddique T, Mohandas TK, Becker CM and Betz H. (1990) Alpha subunit variants of the human glycine receptor: primary structures, functional expression and chromosomal localization of the corresponding genes. EMBO J. 9: 771-6 [PMID:2155780]

32. Grudzinska J, Schemm R, Haeger S, Nicke A, Schmalzing G, Betz H and Laube B. (2005) The beta subunit determines the ligand binding properties of synaptic glycine receptors. Neuron 45: 727-39 [PMID:15748848]

33. Grünert U and Ghosh KK. (1999) Midget and parasol ganglion cells of the primate retina express the alpha1 subunit of the glycine receptor. Vis. Neurosci. 16: 957-66 [PMID:10580731]

34. Grünert U and Wässle H. (1993) Immunocytochemical localization of glycine receptors in the mammalian retina. J. Comp. Neurol. 335: 523-37 [PMID:8227534]

35. Han Y, Li P and Slaughter MM. (2004) Selective antagonism of rat inhibitory glycine receptor subunits $J$. Physiol. (Lond.) 554: 649-58 [PMID:14645455]

36. Handford CA, Lynch JW, Baker E, Webb GC, Ford JH, Sutherland GR and Schofield PR. (1996) The human glycine receptor beta subunit: primary structure, functional characterisation and chromosomal localisation of the human and murine genes. Brain Res. Mol. Brain Res. 35: 211-9 [PMID:8717357]

37. Hartenstein B, Schenkel J, Kuhse J, Besenbeck B, Kling C, Becker CM, Betz H and Weiher H. (1996) Low level expression of glycine receptor beta subunit transgene is sufficient for phenotype correction in spastic mice. EMBO J. 15: 1275-82 [PMID:8635460]

38. Harvey RJ, Depner UB, Wässle H, Ahmadi S, Heindl C, Reinold H, Smart TG, Harvey K, Schütz B and Abo-Salem OM et al.. (2004) GlyR alpha3: an essential target for spinal PGE2-mediated inflammatory pain sensitization. Science 304: 884-7 [PMID:15131310]

39. Harvey RJ, Schmieden V, Von Holst A, Laube B, Rohrer H and Betz H. (2000) Glycine receptors containing the alpha4 subunit in the embryonic sympathetic nervous system, spinal cord and male genital ridge. Eur. J. Neurosci. 12: 994-1001 [PMID:10762330]

40. Haverkamp S, Müller U, Zeilhofer HU, Harvey RJ and Wässle H. (2004) Diversity of glycine receptors in the mouse retina: localization of the alpha2 subunit. J. Comp. Neurol. 477: 399-411 [PMID:15329889]

41. Hawthorne R, Cromer BA, Ng HL, Parker MW and Lynch JW. (2006) Molecular determinants of ginkgolide binding in the glycine receptor pore. J. Neurochem. 98: 395-407 [PMID:16805834]

42. Heads JA, Hawthorne RL, Lynagh T and Lynch JW. (2008) Structure-activity analysis of ginkgolide binding in the glycine receptor pore. J. Neurochem. 105: 1418-27 [PMID:18221374]

43. Heinze L, Harvey RJ, Haverkamp S and Wässle H. (2007) Diversity of glycine receptors in the mouse retina: localization of the alpha4 subunit. J. Comp. Neurol. 500: 693-707 [PMID:17154252]

44. Hejazi N, Zhou C, Oz M, Sun H, Ye JH and Zhang L. (2006) Delta9-tetrahydrocannabinol and endogenous cannabinoid anandamide directly potentiate the function of glycine receptors. Mol. Pharmacol. 69: 991-7 [PMID:16332990]

45. Hibbs RE and Gouaux E. (2011) Principles of activation and permeation in an anion-selective Cys-loop receptor. Nature 474: 54-60 [PMID:21572436]

46. Hirzel K, Müller U, Latal AT, Hülsmann S, Grudzinska J, Seeliger MW, Betz H and Laube B. (2006) 
Hyperekplexia phenotype of glycine receptor alpha1 subunit mutant mice identifies $\mathrm{Zn}(2+)$ as an essential endogenous modulator of glycinergic neurotransmission. Neuron 52: 679-90 [PMID:17114051]

47. Holland KD, Fleming MT, Cheek S, Moran JL, Beier DR and Meisler MH. (2006) De novo exon duplication in a new allele of mouse Glra1 (spasmodic). Genetics 174: 2245-7 [PMID:17028313]

48. Howard RJ, Murail S, Ondricek KE, Corringer PJ, Lindahl E, Trudell JR and Harris RA. (2011) Structural basis for alcohol modulation of a pentameric ligand-gated ion channel. Proc. Natl. Acad. Sci. U.S.A. 108: 12149-54 [PMID:21730162]

49. Huang X, Chen H, Michelsen K, Schneider S and Shaffer PL. (2015) Crystal structure of human glycine receptor- $\alpha 3$ bound to antagonist strychnine. Nature 526: 277-80 [PMID:26416729]

50. Jensen $A A$ and Kristiansen U. (2004) Functional characterisation of the human alpha1 glycine receptor in a fluorescence-based membrane potential assay. Biochem. Pharmacol. 67: 1789-99 [PMID:15081878]

51. Kingsmore SF, Giros B, Suh D, Bieniarz M, Caron MG and Seldin MF. (1994) Glycine receptor betasubunit gene mutation in spastic mouse associated with LINE-1 element insertion. Nat. Genet. 7: 136-41 [PMID:7920630]

52. Kingsmore SF, Suh D and Seldin MF. (1994) Genetic mapping of the glycine receptor alpha 3 subunit on mouse chromosome 8. Mamm. Genome 5: 831-2 [PMID:7894176]

53. Kirsch J. (2006) Glycinergic transmission. Cell Tissue Res. 326: 535-40 [PMID:16807723]

54. Kling C, Koch M, Saul B and Becker CM. (1997) The frameshift mutation oscillator (Glra1(spd-ot)) produces a complete loss of glycine receptor alpha1-polypeptide in mouse central nervous system. Neuroscience 78: 411-7 [PMID:9145798]

55. Kneussel M and Loebrich S. (2007) Trafficking and synaptic anchoring of ionotropic inhibitory neurotransmitter receptors. Biol. Cell 99: 297-309 [PMID:17504238]

56. Kondratskaya EL, Betz H, Krishtal OA and Laube B. (2005) The beta subunit increases the ginkgolide B sensitivity of inhibitory glycine receptors. Neuropharmacology 49: 945-51 [PMID:16125206]

57. Kruger W, Gilbert D, Hawthorne R, Hryciw DH, Frings S, Poronnik P and Lynch JW. (2005) A yellow fluorescent protein-based assay for high-throughput screening of glycine and GABAA receptor chloride channels. Neurosci. Lett. 380: 340-5 [PMID:15862914]

58. Kuhse J, Kuryatov A, Maulet Y, Malosio ML, Schmieden V and Betz H. (1991) Alternative splicing generates two isoforms of the alpha 2 subunit of the inhibitory glycine receptor. FEBS Lett. 283: 73-7 [PMID:1645300]

59. Kuhse J, Schmieden V and Betz H. (1990) Identification and functional expression of a novel ligand binding subunit of the inhibitory glycine receptor. J. Biol. Chem. 265: 22317-20 [PMID:2176214]

60. Kumar A, Basak S, Rao S, Gicheru Y, Mayer ML, Sansom MSP and Chakrapani S. (2020) Mechanisms of activation and desensitization of full-length glycine receptor in lipid nanodiscs. Nat Commun 11: 3752 [PMID:32719334]

61. Kumar DV, Nighorn A and St John PA. (2002) Role of Nova-1 in regulating alpha2N, a novel glycine receptor splice variant, in developing spinal cord neurons. J. Neurobiol. 52: 156-65 [PMID:12124753]

62. Laube B, Kuhse J, Rundström N, Kirsch J, Schmieden V and Betz H. (1995) Modulation by zinc ions of native rat and recombinant human inhibitory glycine receptors. J. Physiol. (Lond.) 483 ( Pt 3): 613-9 [PMID:7776247]

63. Laube B, Langosch D, Betz H and Schmieden V. (1995) Hyperekplexia mutations of the glycine receptor unmask the inhibitory subsite for beta-amino-acids. Neuroreport 6: 897-900 [PMID:7542038]

64. Laube B, Maksay G, Schemm R and Betz H. (2002) Modulation of glycine receptor function: a novel approach for therapeutic intervention at inhibitory synapses? Trends Pharmacol. Sci. 23: 519-27 [PMID:12413807]

65. Lozovaya N, Yatsenko N, Beketov A, Tsintsadze T and Burnashev N. (2005) Glycine receptors in CNS neurons as a target for nonretrograde action of cannabinoids. J. Neurosci. 25: 7499-506 [PMID:16107637]

66. Lynch JW. (2004) Molecular structure and function of the glycine receptor chloride channel.Physiol. Rev. 84: 1051-95 [PMID:15383648]

67. Lynch JW and Chen X. (2008) Subunit-specific potentiation of recombinant glycine receptors by NV-31, a bilobalide-derived compound. Neurosci. Lett. 435: 147-51 [PMID:18329806]

68. Lynch JW, Jacques P, Pierce KD and Schofield PR. (1998) Zinc potentiation of the glycine receptor chloride channel is mediated by allosteric pathways. J. Neurochem. 71: 2159-68 [PMID:9798943]

69. Lynch JW, Rajendra S, Barry PH and Schofield PR. (1995) Mutations affecting the glycine receptor agonist transduction mechanism convert the competitive antagonist, picrotoxin, into an allosteric potentiator. J. Biol. Chem. 270: 13799-806 [PMID:7775436]

70. Lynch JW, Rajendra S, Pierce KD, Handford CA, Barry PH and Schofield PR. (1997) Identification of intracellular and extracellular domains mediating signal transduction in the inhibitory glycine receptor chloride channel. EMBO J. 16: 110-20 [PMID:9009272]

71. Machu TK. (1998) Colchicine competitively antagonizes glycine receptors expressed in Xenopus oocytes. Neuropharmacology 37: 391-6 [PMID:9681937]

72. Machu TK, Mihic SJ and Dildy-Mayfield JE. (1998) Selective actions of a detergent on ligand-gated ion channels expressed in Xenopus oocytes. J. Pharmacol. Exp. Ther. 284: 32-6 [PMID:9435157]

73. Maksay G, Laube B and Betz H. (1999) Selective blocking effects of tropisetron and atropine on recombinant glycine receptors. J. Neurochem. 73: 802-6 [PMID:10428078]

74. Maksay G, Laube B and Betz H. (2001) Subunit-specific modulation of glycine receptors by neurosteroids. Neuropharmacology 41: 369-76 [PMID:11522328] 
75. Maksay G, Laube B, Schemm R, Grudzinska J, Drwal M and Betz H. (2009) Different binding modes of tropeines mediating inhibition and potentiation of alpha1 glycine receptors. J. Neurochem. 109: 1725-32 [PMID:19383091]

76. Malosio ML, Grenningloh G, Kuhse J, Schmieden V, Schmitt B, Prior P and Betz H. (1991) Alternative splicing generates two variants of the alpha 1 subunit of the inhibitory glycine receptor. J. Biol. Chem. 266: 2048-53 [PMID:1703526]

77. Malosio ML, Marquèze-Pouey B, Kuhse $\mathrm{J}$ and Betz H. (1991) Widespread expression of glycine receptor subunit mRNAs in the adult and developing rat brain. EMBO J.10: 2401-9 [PMID:1651228]

78. Mangin JM, Nguyen L, Gougnard C, Hans G, Rogister B, Belachew S, Moonen G, Legendre P and Rigo JM. (2005) Developmental regulation of beta-carboline-induced inhibition of glycine-evoked responses depends on glycine receptor beta subunit expression. Mol. Pharmacol. 67: 1783-96 [PMID:15722459]

79. Mascia MP, Mihic SJ, Valenzuela CF, Schofield PR and Harris RA. (1996) A single amino acid determines differences in ethanol actions on strychnine-sensitive glycine receptors. Mol. Pharmacol. 50: 402-6 [PMID:8700149]

80. Mascia MP, Trudell JR and Harris RA. (2000) Specific binding sites for alcohols and anesthetics on ligandgated ion channels. Proc. Natl. Acad. Sci. U.S.A. 97: 9305-10 [PMID:10908659]

81. Matzenbach B, Maulet Y, Sefton L, Courtier B, Avner P, Guénet JL and Betz H. (1994) Structural analysis of mouse glycine receptor alpha subunit genes. Identification and chromosomal localization of a novel variant. J. Biol. Chem. 269: 2607-12 [PMID:7507926]

82. Meier JC, Henneberger C, Melnick I, Racca C, Harvey RJ, Heinemann U, Schmieden V and Grantyn R. (2005) RNA editing produces glycine receptor alpha3(P185L), resulting in high agonist potency. Nat. Neurosci. 8: 736-44 [PMID:15895087]

83. Melendrez CS and Meizel S. (1996) Immunochemical identification of the glycine receptor/Cl-channel in porcine sperm. Biochem. Biophys. Res. Commun. 223: 675-8 [PMID:8687455]

84. Miller PS, Beato M, Harvey RJ and Smart TG. (2005) Molecular determinants of glycine receptor alphabeta subunit sensitivities to Zn2+-mediated inhibition. J. Physiol. (Lond.) 566: 657-70 [PMID:15905212]

85. Miller PS, Da Silva HM and Smart TG. (2005) Molecular basis for zinc potentiation at strychnine-sensitive glycine receptors. J. Biol. Chem. 280: 37877-84 [PMID:16144831]

86. Miller PS, Harvey RJ and Smart TG. (2004) Differential agonist sensitivity of glycine receptor alpha2 subunit splice variants. Br. J. Pharmacol. 143: 19-26 [PMID:15302677]

87. Moss SJ and Smart TG. (2001) Constructing inhibitory synapses. Nat. Rev. Neurosci. 2: 240-50 [PMID:11283747]

88. Mülhardt C, Fischer M, Gass P, Simon-Chazottes D, Guénet JL, Kuhse J, Betz H and Becker CM. (1994) The spastic mouse: aberrant splicing of glycine receptor beta subunit mRNA caused by intronic insertion of L1 element. Neuron 13: 1003-15 [PMID:7946325]

89. Nguyen L, Malgrange B, Belachew S, Rogister B, Rocher V, Moonen G and Rigo JM. (2002) Functional glycine receptors are expressed by postnatal nestin-positive neural stem/progenitor cells. Eur. J. Neurosci. 15: 1299-305 [PMID:11994124]

90. Nikolic Z, Laube B, Weber RG, Lichter P, Kioschis P, Poustka A, Mülhardt C and Becker CM. (1998) The human glycine receptor subunit alpha3. Glra3 gene structure, chromosomal localization, and functional characterization of alternative transcripts. J. Biol. Chem. 273: 19708-14 [PMID:9677400]

91. Nury H, Van Renterghem C, Weng Y, Tran A, Baaden M, Dufresne V, Changeux JP, Sonner JM, Delarue $M$ and Corringer PJ. (2011) X-ray structures of general anaesthetics bound to a pentameric ligand-gated ion channel. Nature 469: 428-31 [PMID:21248852]

92. Oertel J, Villmann C, Kettenmann H, Kirchhoff F and Becker CM. (2007) A novel glycine receptor beta subunit splice variant predicts an unorthodox transmembrane topology. Assembly into heteromeric receptor complexes. J. Biol. Chem. 282: 2798-807 [PMID:17145751]

93. Pfeiffer F, Graham D and Betz H. (1982) Purification by affinity chromatography of the glycine receptor of rat spinal cord. J. Biol. Chem. 257: 9389-93 [PMID:6286620]

94. Pinto LH, Grünert U, Studholme K, Yazulla S, Kirsch J and Becker CM. (1994) Glycine receptors in the retinas of normal and spastic mutant mice. Invest. Ophthalmol. Vis. Sci. 35: 3633-9 [PMID:8088953]

95. Pitt SJ, Sivilotti LG and Beato M. (2008) High intracellular chloride slows the decay of glycinergic currents. J. Neurosci. 28: 11454-67 [PMID:18987182]

96. Pribilla I, Takagi T, Langosch D, Bormann J and Betz H. (1992) The atypical M2 segment of the beta subunit confers picrotoxinin resistance to inhibitory glycine receptor channels. EMBO J. 11: 4305-11 [PMID:1385113]

97. Probst A, Cortés R and Palacios JM. (1986) The distribution of glycine receptors in the human brain. A light microscopic autoradiographic study using [3H]strychnine. Neuroscience 17: 11-35 [PMID:3008022]

98. Rajendra S, Lynch JW, Pierce KD, French CR, Barry PH and Schofield PR. (1995) Mutation of an arginine residue in the human glycine receptor transforms beta-alanine and taurine from agonists into competitive antagonists. Neuron 14: 169-75 [PMID:7826634]

99. Rees MI, Lewis TM, Kwok JB, Mortier GR, Govaert P, Snell RG, Schofield PR and Owen MJ. (2002) Hyperekplexia associated with compound heterozygote mutations in the beta-subunit of the human inhibitory glycine receptor (GLRB). Hum. Mol. Genet. 11: 853-60 [PMID:11929858]

100. Rundström N, Schmieden V, Betz H, Bormann J and Langosch D. (1994) Cyanotriphenylborate: subtypespecific blocker of glycine receptor chloride channels. Proc. Natl. Acad. Sci. U.S.A. 91: 8950-4 [PMID:8090751] 
101. Ryan SG, Buckwalter MS, Lynch JW, Handford CA, Segura L, Shiang R, Wasmuth JJ, Camper SA, Schofield P and O'Connell P. (1994) A missense mutation in the gene encoding the alpha 1 subunit of the inhibitory glycine receptor in the spasmodic mouse. Nat. Genet. 7: 131-5 [PMID:7920629]

102. Sassoè-Pognetto M, Wässle H and Grünert U. (1994) Glycinergic synapses in the rod pathway of the rat retina: cone bipolar cells express the alpha 1 subunit of the glycine receptor. J. Neurosci. 14: 5131-46 [PMID:8046473]

103. Sato K, Zhang JH, Saika T, Sato M, Tada K and Tohyama M. (1991) Localization of glycine receptor alpha 1 subunit mRNA-containing neurons in the rat brain: an analysis using in situ hybridization histochemistry. Neuroscience 43: 381-95 [PMID:1656320]

104. Sato Y, Son JH and Meizel S. (2000) The mouse sperm glycine receptor/chloride channel: cellular localization and involvement in the acrosome reaction initiated by glycine. J. Androl. 21: 99-106 [PMID:10670525]

105. Saul B, Schmieden V, Kling C, Mülhardt C, Gass P, Kuhse J and Becker CM. (1994) Point mutation of glycine receptor alpha 1 subunit in the spasmodic mouse affects agonist responses. FEBS Lett. 350: 71-6 [PMID:8062927]

106. Schmieden V, Kuhse J and Betz H. (1993) Mutation of glycine receptor subunit creates beta-alanine receptor responsive to GABA. Science 262: 256-8 [PMID:8211147]

107. Shan Q, Haddrill JL and Lynch JW. (2001) Ivermectin, an unconventional agonist of the glycine receptor chloride channel. J. Biol. Chem. 276: 12556-64 [PMID:11278873]

108. Simmonds MA and Turner JP. (1985) Antagonism of inhibitory amino acids by the steroid derivative RU5135. Br. J. Pharmacol. 84: 631-5 [PMID:3986429]

109. Sontheimer H, Becker CM, Pritchett DB, Schofield PR, Grenningloh G, Kettenmann H, Betz H and Seeburg PH. (1989) Functional chloride channels by mammalian cell expression of rat glycine receptor subunit. Neuron 2: 1491-7 [PMID:2483325]

110. Steinbach JH, Bracamontes J, Yu L, Zhang P and Covey DF. (2000) Subunit-specific action of an anticonvulsant thiobutyrolactone on recombinant glycine receptors involves a residue in the M2 membrane-spanning region. Mol. Pharmacol. 58: 11-7 [PMID:10860922]

111. Supplisson $S$ and Chesnoy-Marchais D. (2000) Glycine receptor beta subunits play a critical role in potentiation of glycine responses by ICS-205,930. Mol. Pharmacol. 58: 763-70 [PMID:10999946]

112. Takahashi T, Momiyama A, Hirai K, Hishinuma F and Akagi H. (1992) Functional correlation of fetal and adult forms of glycine receptors with developmental changes in inhibitory synaptic receptor channels. Neuron 9: 1155-61 [PMID:1281418]

113. van den Pol AN and Gorcs T. (1988) Glycine and glycine receptor immunoreactivity in brain and spinal cord. J. Neurosci. 8: 472-92 [PMID:2892900]

114. Vandenberg RJ, Handford CA and Schofield PR. (1992) Distinct agonist- and antagonist-binding sites on the glycine receptor. Neuron 9: 491-6 [PMID:1326295]

115. Webb TI and Lynch JW. (2007) Molecular pharmacology of the glycine receptor chloride channel.Curr. Pharm. Des. 13: 2350-67 [PMID:17692006]

116. Werman R, Davidoff RA and Aprison MH. (1967) Inhibition of motoneurones by iontophoresis of glycine. Nature 214: 681-3 [PMID:4292803]

117. Xiong W, Cheng K, Cui T, Godlewski G, Rice KC, Xu Y and Zhang L. (2011) Cannabinoid potentiation of glycine receptors contributes to cannabis-induced analgesia. Nat. Chem. Biol. 7: 296-303 [PMID:21460829]

118. Yang Z, Aubrey KR, Alroy I, Harvey RJ, Vandenberg RJ and Lynch JW. (2008) Subunit-specific modulation of glycine receptors by cannabinoids and $\mathrm{N}$-arachidonyl-glycine. Biochem. Pharmacol. 76: 1014-23 [PMID:18755158]

119. Yang Z, Cromer BA, Harvey RJ, Parker MW and Lynch JW. (2007) A proposed structural basis for picrotoxinin and picrotin binding in the glycine receptor pore. J. Neurochem. 103: 580-9 [PMID:17714449]

120. Yang Z, Ney A, Cromer BA, Ng HL, Parker MW and Lynch JW. (2007) Tropisetron modulation of the glycine receptor: femtomolar potentiation and a molecular determinant of inhibition. J. Neurochem. 100: 758-69 [PMID:17181559]

121. Yevenes GE, Moraga-Cid G, Avila A, Guzmán L, Figueroa M, Peoples RW and Aguayo LG. (2010) Molecular requirements for ethanol differential allosteric modulation of glycine receptors based on selective Gbetagamma modulation. J. Biol. Chem. 285: 30203-13 [PMID:20647311]

122. Yevenes GE, Moraga-Cid G, Guzmán L, Haeger S, Oliveira L, Olate J, Schmalzing G and Aguayo LG. (2006) Molecular determinants for $\mathrm{G}$ protein betagamma modulation of ionotropic glycine receptors. $J$. Biol. Chem. 281: 39300-7 [PMID:17040914]

123. Yevenes GE, Peoples RW, Tapia JC, Parodi J, Soto X, Olate J and Aguayo LG. (2003) Modulation of glycine-activated ion channel function by G-protein betagamma subunits. Nat. Neurosci. 6: 819-24 [PMID:12858180]

124. Yevenes GE and Zeilhofer HU. (2011) Allosteric modulation of glycine receptors.Br. J. Pharmacol. 164: 224-36 [PMID:21557733]

125. Young TL and Cepko CL. (2004) A role for ligand-gated ion channels in rod photoreceptor development. Neuron 41: 867-79 [PMID:15046720]

126. Young-Pearse TL, Ivic L, Kriegstein AR and Cepko CL. (2006) Characterization of mice with targeted deletion of glycine receptor alpha 2. Mol. Cell. Biol. 26: 5728-34 [PMID:16847326]

127. Zarbin MA, Wamsley JK and Kuhar MJ. (1981) Glycine receptor: light microscopic autoradiographic 
localization with [3H]strychnine. J. Neurosci. 1: 532-47 [PMID:6286895] 